AperTO - Archivio Istituzionale Open Access dell'Università di Torino

Teacher quality and school improvement: What is the role of research?

This is a pre print version of the following article:

Original Citation:

Availability:

This version is available http://hdl.handle.net/2318/158550

since $2015-12-12 T 12: 14: 29 Z$

Published version:

DOI:10.1080/03054985.2015.1023013

Terms of use:

Open Access

Anyone can freely access the full text of works made available as "Open Access". Works made available under a Creative Commons license can be used according to the terms and conditions of said license. Use of all other works requires consent of the right holder (author or publisher) if not exempted from copyright protection by the applicable law. 


\section{(2) \\ UNIVERSITÀ DEGLI STUDI DI TORINO}

This is an author version of the contribution published on:

Questa è la versione dell'autore dell'opera:

Oxford Review of Education, volume 41, issue 2, 2015, http://www.tandfonline.com/doi/full/10.1080/03050068.2015.1033249

ovvero Monica Mincu, Teacher quality and school improvement: What is the role of research?

pp. 253-269

The definitive version is available at:

La versione definitiva è disponibile alla URL:

http://www.tandfonline.com/doi/pdf/10.1080/03054985.2015.1023013 


\title{
Teacher quality and school improvement: What is the role of research?
}

\author{
Monica Elena Mincu ${ }^{1}$ \\ Department of Philosophy and Educational Sciences, University of Torino, Italy \\ Via Gaudenzio Ferrari 9/11, Torino, 10124, Italy Tel.+39.0116703164; \\ monica.mincu@unito.it
}

In a rapidly changing world, students' success depends upon the schools' capacity to deal with their specific instructional needs. Thus, effective teaching plays the role of a unique protective factor that may reduce and even close the achievement gap. Two broad questions structure this study: What is the research contribution to teacher quality and improvement? What elements of teacher quality support school improvement? As one driver of school improvement, teacher quality is especially pertinent for underperforming students, while school improvement is much more likely to emerge through collective capacity building. More specifically, I will argue that research-derived knowledge is key to ensuring both effective learning processes and whole school improvement.

Keywords: teacher effectiveness, school improvement, teacher education, research knowledge, teacher quality

\section{Introduction}

A number of studies (Ko \& Sammons; 2012; Cordingley \& Mitchell, 2013; Earl \& Timperley, 2008; Earl \& Katz, 2006) suggest that the use of research is a characteristic of a high quality teacher, who may play the role of an agent of improvement within schools. The school's capacity to improve is upheld, inter alia, by teachers' knowledge, skills and dispositions, and the creation of a professional community (Hopkins, 2013). However, how research interacts with policy and practice is a matter of institutional dynamic, which mediates its interpretation and effect (Levin, 2011; Earl \& Timperley, 2008; Coburn, 2001).

In addition, school improvement requires research-derived expert knowledge, as demonstrated, for instance, by the Alberta School Improvement Initiative [AISI] (Hargreaves Crockere, Davis, McEwen, Sahlberg, Shirley, \& Sumara, 2009; Foster, Wright, \& McRae, 2008). At the same time, school leadership is second only to teachers in its effect on students (SeashoreLouis, Leithwood, Wahlstrom, \& Anderson, 2010; Leithwood, Day, Sammons, Harris \& Hopkins, 2004). Instruction-focused, distributed and transformational leadership is a crucial factor in improvement (Leithwood \& Duke, 1999; Mulford, 2010). Instructional matters as a core element of improvement also require research evidence of what works in practice, though contextually revisited and reinvented by expert teachers.

Since "knowledge can come from multiple sources" (Seashore-Louis, 2010), only some of these sources have the potential of including a research-based input. The epistemological debate on different types of knowledge is a complex one (Furlong, 2013). However, it is possible to identify two major loci that contribute to the development of the teacher as a professional - the university and the school. Thus, in line with the idea of radial transformation, "combining inside-out and outside-in change" processes (Hargreaves, 2009), this article proposes two ways in which research may both inform and emerge from practice and, therefore, contribute to school improvement:

\footnotetext{
${ }^{1}$ Email: monica.mincu@unito.it
} 
- Expert knowledge emerging from "inside", in some cases limited to classrooms or departments or, in others, creating a wider professional learning community [PLC]. The locus of expert knowledge creation is internal, and leads to transformational processes. Examples of this are the 'lesson study' approach in Japan, collaborative planning in Finland (OECD, 2012), and subject-based teaching study groups in Shanghai (OECD, 2011).

- Expert knowledge as an input from 'outside', for instance in the form of a higher education researcher or other 'expert' provider. The locus of expert knowledge creation may, necessarily, be external in those cases in which quality teachers may be insufficient or not necessarily supportive of transformational processes beyond their classes;

Against this background, the argument advanced in this article is twofold: on the one hand, the issue of teacher quality as a driver of school improvement is especially pertinent for 'low achieving' students and for those schools that are viewed as 'underperforming'. In this context, the role of expert knowledge, whether it results from external intervention or internal generation, is vital. On the other hand, school improvement is much more likely to emerge as a result of collective capacity building than through the application of a series of 'external' accountability measures. For such improvement to take place there needs to be a focus on the development of teachers' knowledge, skills and commitment. The findings from this study show that a continuous infusion of new knowledge is key to ensuring effective learning processes in the classroom and whole school improvement - inspired by distributed, instructional and inquiry-minded leadership.

To develop my understanding of the research contribution to teacher quality and school improvement, I have formulated a broad research question: Which elements of teacher quality support school improvement and are most effective with underperforming students? This question has been further broken down into several sub-questions, as follows:

1. Do research-based teacher competences relate to teacher effectiveness, particularly of a differential type, and if so, how? (discussed in the section Effective for whom, about what, and in which context?)

2. Does teacher education relate to teacher quality and to students' achievement? (in: Teacher education as a source of expert knowledge)

3. Does teachers' capacity to innovate through collaboration contribute to school improvement, and if so, how? (in: The need for capacity building)

4. How do school leaders contribute to a culture of change? (in: The role of school leaders)

5. What is the role of research-derived knowledge in school improvement? (in: Research as a pillar of school improvement)

This article is positioned at the intersection of several strands of academic inquiry and engages with a complex network of topics: (1) educational change, (2) teacher quality and effectiveness, (3) school improvement, (3) equity, and (5) the role of research. An initial decision to draw exclusively on research reviews to produce a meta-review has been reconsidered in order to include the breadth of scholarship illuminating this complex conceptual nexus. In addition, the role of research was not immediately visible while searching for titles and abstracts of specific publications on electronic databases (such as EBSCO and ERIC, complemented by the ACER and the OECD on-line resources). Different conceptual proxies proved helpful in various circumstances, such as teaching towards/with meta-cognition, when investigating the role of research to a quality teacher. Some topics under discussion, such as the effect of teacher education, particular degrees or coursework on student achievement, would require major research reviews to cover each effectively (e.g. Wayne $\&$ Youngs, 2003). This article indicates some other recent sources supporting a positive correlation 
between teacher education and achievement. The focus of my work lies, however, on the nexus between teacher training and teacher quality, which appears as clearly positive. Another issue concerns the possibility of bringing about school improvement through innovation in teacher behaviour and/or through accountability measures. While reporting scholarship referring to both strategies, this article focuses on teacher behaviour and on bottom-up and inside-out measures of improvement, in line with my research question and with recent research reviews (Thurlings, Evers, $\&$ Vermeulen, 2014). The rather wide-ranging inclusion criteria in this study are: (1) data collected world-wide, particularly in European and English speaking countries; (2) studies, research reviews and meta-analysis reporting correlations between various concepts under investigation; (3) scholarship reporting best practice in some key contexts of school improvement.

The findings draw upon research reviews (Alton-Lee, 2003; Collins, 2013; DarlingHammond; Hattie, 2009; Higgins et al., 2005; Ko \& Sammons, 2012; Muijs, et al, 2004; Reynolds et al, 2014; Sammons, 2007; Seidel \& Shavelson 2007; etc), handbooks in the fields under consideration (Hargreaves et al, 2007; Murphy \& Seashore, 1999; etc), peer-reviewed articles and practitioner-focused materials reporting relevant experience in the field of the school improvement (Elliott, 2009; Fullan, 2007, 2011; Furlong et al, 2003; etc). OECD studies (2011, 2012) and best practice in school improvement research, in contexts such as the Canadian AISI project, belong in this later category. These and other scholarly articles dealing with pertinent experience around the world (Darling-Hammond, 2010; Toom et al, 2010; etc) provide comparative data. Drawing together this breadth of material, my major aim is to conceptually clarify the relationship between teacher quality and school improvement as research derived.

\section{Teachers matter and schools make a difference}

During the 1960s and 1970s, influential studies claimed that individual characteristics and socioeconomic backgrounds were the most influential factors accounting for pupils' achievement. At the same time, the effects of schooling processes were seen as weakly related to achievement. Subsequent studies have challenged this perspective and showed the existence of significant effects at classroom, departmental and school level (Reynolds, Sammons, De Fraine, Van Damme, Townsend, Teddlie \& Stringfield, 2014).

Although there are different findings concerning the balance between home and school factors, when it comes to the impact of school-level factors, research demonstrates that, on average, schools account for between 5 and $18 \%$ of achievement differences, after initial differences are controlled for (Sammons, 2007). It is widely accepted that there can be internal variations in effectiveness at departmental or class level, and that teacher effects tend to be substantially larger than school differences. These are especially strong in primary schools, where pupils tend to spend most of the day with a single teacher, and in developing countries. Research studies suggest a range of between $20 \%$ and $40 \%$ (Ko \& Sammons, 2012). Teacher quality appears therefore to be a crucial variable at the classroom level. To sum up, (1) the most effective teachers are at least five times as effective as the least effective; (2) teacher quality may close the achievement gap in both primary and secondary schools; and (3) good teachers continue to benefit students for at least two years after they have stopped teaching them (Wiliam, 2013).

\section{Effective for whom, effective about what, and effective in which context?}

Teacher effectiveness encompasses factors that reach beyond the classroom (for example, preexisting teacher characteristics, teacher behaviour and expectations, teacher training, external and internal teaching contexts). In addition, teacher effectiveness is also derived from the consistency of teachers' effects in the classroom, in terms of time stability, subject consistency, differentiated roles and types of student (Ko \& Sammons, 2012). 
At the classroom level, overall teaching quality and expectations are most relevant, while curriculum coverage, instructional approaches and the provision of good quality feedback to students are key components in addressing the educational needs of so-called lower achievers. Structured teaching is particularly efficient for the building of cognitive attainment in basic skills and in working with socio-economically disadvantaged groups. Constructivist teaching approaches are less appropriate for younger, low-attaining and low SES children (Hattie, 2009; Rowe, 2006; Sammons, 2007; Reynolds et al, 2014). Both, however, are useful in specific circumstances and in the correct 'order' (Rowe, 2006): direct instruction, followed by constructivist approaches. However, for maximum impact, a wide repertoire of pedagogic approaches, personalised to meet the needs of individual students and particular cohorts, is required (Hopkins, 2013). In short, a combination of 'direct' (instructional) and 'student oriented' (constructionist) methods are needed, while an over-reliance on either approach is not recommended (OECD, 2012). However the balance is struck, technology appears to be a significant cognitive resource that may reduce extraneous processing, manage essential knowledge and foster generative processing (Mayer, 2012).

Continuous and comprehensive assessment by teachers is also required to strengthen students' knowledge and meta-cognitive skills. The development of meta-cognition is particularly relevant for closing or narrowing the gap between low achievers, including minority students, and high achievers (Alton-Lee, 2003). Higgins and colleagues (2005) show that the greatest effects were generated by metacognitive strategies, cognitive acceleration, and instrumental enrichment, with the greatest effects in mathematics, science and reading. Moreover, "[such] meta-cognitive skills are especially beneficial for less able students who might otherwise have difficulty monitoring and self-regulating their own learning" (Leithwood et al, 2010, p. 612; also Reynolds et al, 2014), since usually teachers narrowly focus on basic skills and knowledge. A rich curriculum for deep understanding is needed (Leithwood et al, 2010). In addition, meta-cognition is beneficial for teachers and students alike: teaching with meta-cognition and teaching for meta-cognition (Hartman, 2001 in McCormick, 2003). Appropriate teacher preparation is likely to enhance the ability of the teacher to support the development of students' meta-cognitive processes (Zohar, 1999 and Matanzo \& Harris, 1999 in McCormick, 2003). Hence, possessing a wide repertoire of teaching strategies, extending students' knowledge and promoting meta-cognitive skills, requires researchbased teacher education and reflection on professional practice.

Teaching teams and subject-based departments, as the immediate working contexts, contribute more to differential teacher effectiveness than the schools themselves. Subject teaching inconsistency varies within and between schools and it is larger in secondary schools than primary (Ko \& Sammons, 2012). Another critical issue is that differential teacher effectiveness outweighs the effects of differences in class size and heterogeneity (Darling-Hammond, 2000). Quite different positions are noticeable when it comes to the effects of schools. Some researchers indicate a residual effect of structures, organisational patterns or processes (Rowe, 2006). However, while schools have a significant impact on achievement and behaviour, their influence on the social and affective domain at the individual level is less noticeable, although correlations remain significant and positive. In other words, improving students' attainment can improve self-esteem, engagement and attitudes to school and vice-versa. Significantly, a highly predictable feature of student achievement is the individual teacher's skill in developing interpersonal relationships with students (Hattie, 2009).

Teaching, as most proximal to the executive processes of learning, is of critical importance, most notably pedagogical content knowledge. In fact, "[providing] opportunities for students to engage in domain-specific learning activities was shown to be the component with the highest effect sizes, regardless of domain (reading, mathematics, science), stage of schooling (elementary, secondary), or type of learning outcome (learning processes, motivational-affective, cognitive)" (Seidel \& Shavelson, 2007, p. 483). 
Finally, researchers have raised the question of whether schools and teachers are equally effective for different groups of students. Thus, major research supports the view that schools matter most for underprivileged and/or initially low achieving students. Effective or ineffective schools are especially effective or ineffective for these students (Scheerens \& Bosker, 1997). The possibility to add value for the most vulnerable students calls into question the capacity of teachers to act and make a difference with these pupils. This hints not only at the generic effectiveness of teachers, but also at their specific differentiated effectiveness. This suggests that the distribution of teacher effectiveness is much more uneven in low-SES ineffective schools than in those that draw their students from more advantaged socio-economic backgrounds (Ko \& Sammons, 2012). Hence, teachers can make a greater difference than in high-SES schools (Nye, Konstantopoulos, \& Hedges, 2004). In many countries, in urban and poor rural areas, as well as in minority schools, less qualified teachers are likely to concentrate (Darling-Hammond, 2010).

In brief, research may contribute to a precise diagnosis of effective approaches in various contexts and with diverse students, helping to ensure that teachers acquire a sound pedagogical content knowledge, promoting and extending meta-cognitive skills for all and for lower achieving students in particular.

\section{Teacher education as a source of expert knowledge}

Although the role of teacher education as a predicting variable of students' achievement requires further investigation, the research evidence is encouraging. A number of studies (Angrist \& Lavy, 2001; Greenwald, Hedges, \& Laine, 1996; Raudenbush, Fotiu, \& Cheong, 1999; Greenberg, Rhodes, Ye, \& Stancavage, 2004 in Ingersoll, 2007; Darling-Hammond, 2000) report significant relationships between teacher education, certification and student performance at the levels of the individual teacher, the school, the district and the state (Darling-Hammond, 2002). Research reported by Marzano (2003) suggests that "teacher subject-matter knowledge was related to student achievement only up to a certain point" (p. 64), while the relationship between pedagogical knowledge and student achievement appears to be empirically more strongly sustained. In addition, more experienced and traditionally trained teachers performed better than a sub-sample of new teachers possessing content background but little educational training (Darling-Hammond, Berry \& Thoreson, 2001). Recent studies that comparatively and comprehensively investigate teacher qualifications and certification, their attitudes, and their instructional preferences and practices are less conclusive. For instance, a study in Flanders (Boonen, Van Damme \& Onghena, 2009) reports that teachers' background has no impact on student achievement in reading and spelling, whereas a significant effect is detected in mathematics. Conversely, Palardy and Rumberger (2008) found that teacher background in the United States has no effect on mathematics achievement but that it does have a significant effect on achievement in reading.

However, teacher education produces relevant effects on teachers, which in turn may have beneficial consequences for students and school improvement (Hattie, 2009). Some of this evidence is particularly pertinent. Colosimo (1984) found a quite substantial increase in positive attitudes and self-concept amongst new teachers who had been through a teacher education program. Secondly, pre-service programs offering interpersonal skills training proved effective in changing teacher achievement, skills and attitudes (Joslin, 1980). Finally, professional development improved job performance and satisfaction through increased professional knowledge, affective feelings and satisfaction, as well as positively impacting student outcomes (Harrison, 1980). In addition to these, a more recent study reported that teacher participation in professional development activities accounted for significant amounts of variation in mathematics and science achievement (Weglinsky, 2000 in Marzano, 2003). In this case, and in line with recent research upholding the role played by schools, "teacher experience and involvement in professional development activities accounted for about as much of the variance in student achievement as did student background" (Marzano, 2003, 
p. 64). In one study, teachers prepared in formal teacher education programs felt significantly better prepared for virtually all teaching tasks than those who lacked preparation or who entered teaching through alternative programs (Darling-Hammond, Chung, \& Frelow, 2002).

In this context, Hattie (2009) developed a convincing argument about the positive effects of teacher preparation on teachers' professional development and their day-to-day professional practice in schools, as particularly related to building "lenses and conceptions" (p. 111) that are crucial for a variety of aspects of their work.

Significantly, enhancing the quality of teacher education has proved to be a critical ingredient in the school improvement efforts of the highest-achieving countries across the world. In Finland, Sweden, Norway and The Netherlands, every teacher receives between two and three years of graduate-level preparation before they enter the profession, completely at government expense, including a living stipend. Typically, programs include at least a full year of training in a school connected to the university (Darling-Hammond, 2010). A research component lies at the heart of some of the best teacher education systems and aims to supporting lower achievers. In Shanghai and in Finland "teachers are trained to be action researchers in practice, with the ability to work out ways of ensuring that any student starting to fall behind is helped effectively" (OECD, 2012, p. 14). This action research may take the form of researching teaching, whether one's own or someone else's, may be part of in-service teacher education, continuing professional development or, as in the Finnish case, it may take various forms and be a constitutive part of preservice education (Toom Kynäslahti, Krokfors, Jyrhämä, Byman, Stenberg, Maaranen, \& Kansanen, 2010).

Last but not least, The Best Practice Research Scholarships (Furlong, Salisbury, \& Combes, 2003) offered evidence about the gains in professional judgment when greater use of research and systematic collection of evidence is in place. Effective schools should, therefore, (1) disseminate and study relevant research evidence on effective practices, (2) encourage evidence-informed teacher collaboration and self-reflection as strategies to enhance effectiveness and achieve consistency across all aspects of learning, (3) and encourage monitoring and observation, using appropriate research protocols to support professional learning (Ko \& Sammons, 2012).

In summary, the importance of correctly diagnosing student need and the ability to apply a wide repertoire of appropriate solutions has become part of initial teacher education around the world. To this end, the design of teacher education must be context-specific (Musset, 2010) and should prepare competent teachers for practice in disadvantaged schools. The skills for reflective practice and on-the-job research have come centre stage (OECD, 2011) and, significantly, these are essentially research derived.

\section{The need for capacity building}

Those directly engaged in improvement projects in recent decades agree with Fullan (2007) that what matters most is strengthening the capacity of teachers, rather than tightening the controls over education. In some contexts, recent initiatives invest more in well-prepared and well supported teachers rather than in regulations to direct what they do (Darling-Hammond, 2010; Hargreaves, 2010). Accountability measures by themselves are less effective than teacher motivation and commitment to implement reform (Leithwood et al, 2002).

A new vision of change as a top-down, bottom-up and outside-inside dynamic has informed recent school improvement projects in Alberta. This model of change draws on the premise that actors from inside can greatly benefit from resources, input and actors from outside. Collaboration, networking and partnership with external institutions and experts helps to drive school improvement, such that the infusion of, and the internal professional stimulation provided by, externally sourced expert knowledge empowers a hitherto disempowered teaching community. These 'outside' inputs might take the form of accountability measures, such as the introduction of a school inspection regime, and/or a range of more overtly supportive measures, for instance peer- 
to-peer based partnerships with other schools, advisory support from a local authority or input from a university department of education. On the one hand, inspections have a useful role to play in identifying weaker or failing schools and their need for support (Sammons, 2007). Inspection itself is, however, a crude tool and its usefulness is limited to certain situations. On the other hand, a wide range of public and private actors can provide external support, as showed also by a major review dealing with schools in socioeconomically disadvantaged areas (Muijs, Harris, Chapman, Stoll \& Russ, 2004). Typically, such work might take the form of school-based teams of teachers working to drive up effectiveness and external design teams helping with school redesign, ensuring that what is offered is what is required internally (Thomson, 2010).

Empirical and theoretical research clearly links teachers' willingness to embrace change, and to work positively for its implementation, with teacher morale in the setting in which the change is required. This is, of course, difficult; the identification of the need for change, especially if identified through an external and public inspection or through consistently poor examination outcomes for students, can itself sap morale. Conversely, a pre-existing culture of strong researchbased teacher preparation and evidence-based practice is more likely to generate innovative visions of teaching and schooling, and better performance (Collins, Tagney \& Newham, 2012). In fact, from the whole school improvement scholarship it emerged that the dimension of beliefs and understandings is crucial to generate school change.

The right mix between accountability and capacity building, with the latter in a dominant position in order to foster intrinsic motivation is therefore crucial. Improving systems in developing countries tended to have an equal proportion of accountability and capacity-building activities, while in the good and best performing systems in developed countries the percentages accorded to professional learning and accountability were $78 \%$ and $22 \%$ respectively. Fullan (2011) concludes that, even in the worst cases, accountability was a co-equal driver, not a dominant one. In the case of Ontario, the government abolished the paper-and-pencil testing of new teachers, which the profession had seen as punitive, and replaced this with more supportive policies. As a result, staffing levels have increased, teacher workload has been reduced and preparation time has increased (Levin, 2010).

More broadly, and building on the kind of accountability support balance argued for here, schools that have overcome obstacles and improved are able to contribute their own knowledge and practice of school improvement to a wider community of schools. Sometimes, disadvantaged schools embed expertise and practices that are exemplary and from which the whole system can benefit (OECD, 2012).

This kind of analysis has the potential to produce a paradigm shift. It draws on theories of human motivation and decades of experience with school change, and brings to new life the idea of teacher professionalism. This is in line with ideas of democratic and collaborative professionalism (Whitty, 2006). Teachers who have acquired new skills as researchers is the main feature of the Alberta initiative (Hargreaves et al, 2009). This strategy is based on self-initiated changes, a culture of teacher-inquiry, decentralised relationships with districts and networks with various institutions, including universities. In fact, the AISI project is a case in point of improvement externally stimulated by research and internally balanced through reflection. There is a striking awareness of tight links with university-based researchers:

Several districts have collaborated with university faculty at various points in their project cycles and received assistance in designing surveys, studying student achievement data, and modifying assessment practices The requirement to infuse current research into AISI-related projects has sparked considerable connectivity, as each district developed strategies and structures to gather and infuse new thinking into its system (Sumara \& Davies, 2009). 
This new vision of change, best exemplified by the Alberta and Ontario cases, is effectively captured in the words of one teacher: "We are not a chain of command, but a chain of trust" (Sumara \& Davies, 2009, p. 44).

\section{The role of school leaders}

It is well established that leaders play a critical role in both pupils' achievement and school improvement more broadly (Day et al, 2000; Leithwood, Day, Sammons, Harris, \& Hopkins, 2006). Effective leadership is distributed, and shared, instruction-focused and supportive of teachers' morale. Leaders set directions (shared visions, high performance expectations), develop people (individual support, intellectual and emotional stimulation, modelling) and redesign the organization (collaborative cultures and structures, building productive relations with parents and the community) (Leithwood, Seashore Louis, Anderson \& Wahlstrom, 2004).

In this analysis, school leaders are crucial for shaping 'trust in schools', which has a dramatic influence, both direct and indirect, on the effectiveness of the school (Bryk \& Schneider, 2002). In addition, McLaughlin and Talbert (2006) find that the quality of leadership at the departmental and/or school level accounts for a significant part of the differences between schools, and between departments within schools. Moreover, school leadership is the starting point for the transformation of low-performing (and) disadvantaged schools (OECD, 2012).

Taking this a step further, leaders are key to both closing the gap and enhancing a culture of research. Three inter-connected modes of enquiry-minded leadership for school improvement have been distinguished (Stoll, Bolam \& Collarbone, 2002): promoting research and evaluation across the school, in departments and by individual classroom teachers; adopting a more systematic approach to collecting, analysing and using data and evidence in the course of on-going work, for example, students' examination results, value-added data and external school inspection reports; seeking out and using relevant and practical research, generated and produced by external researchers.

The prominence now given to data in publicly funded education systems has further underlined the significance of the leader's role. Recent work has focused on the role of school leaders in helping to determine what information is considered worth talking about in the first place (Seashore-Louis, 2010). In synthesis, school leadership is crucial to school improvement and particularly relevant for the transformation of low performing disadvantaged schools (Muijs et al, 2004; OECD, 2012).

\section{Research as a pillar of school improvement}

During the 1990s, the idea of the school as a research institution in itself gained considerable currency. This notion of the school as a research hub was closely aligned with concurrently emerging ideas about schools as self-improving institutions. School improvement was closely tied to teachers' professional development and against this backdrop teachers' (and, in some settings, students') research was actively promoted as facilitating school improvement. The professional development schools in the USA, an expression of this approach, combined the use of academic research with the creation of 'data-rich' environments in which self-evaluation thrived (DarlingHammond, 2005). Teachers acted as action researchers and research leaders, involving students and other members of the school community in the investigative and analytical processes.

A necessary teacher and school inquiry element is essential for both teachers' professional learning and for school improvement, one feeding the other in a virtuous feedback loop, while providing a series of outcomes or incidences that spur teacher reflection. The empirical evidence is clear; the argument put forward in the 1970s by Stenhouse still holds: school and teacher practice can only be improved if teachers are actively and collectively engaged in the investigation of 
problems and produce local and specific solutions (Elliott, 2009; Collins et al, 2012; Hargreaves \& Fullan, 2012; Hopkins, 2013).

In a significant study, Cousins and Leithwood (1993) conclude that genuine and whole school improvement takes place when practitioners share useful information. They also argue that teachers should be involved in the design, delivery and follow-up activities associated with the school improvement project. Why? Because the source of information is a key factor in the use of research findings. Following their analysis, a particular role is now assigned to evidence based and tested practice. The capacity for learning at the local level is linked to changes at the system level through collaboration, networking and systemic improvement (Mourshed, Chijioke, \& Barber, 2010; Fullan, 2007, 2011). Of course, in reality, the ability of teachers to enquire in this way, and to build their commitment to proposed changes as a result, is linked to the availability of the necessary time to explore options, to plan, trial and reflect. The provision of teacher time may require additional funding. Organisational measures are in place in Boston, Japan and Finland, where teachers are given time for joint planning and analysis of teaching practices (Mourshed et al, 2010).

With regard to the use of data and research, in Ontario schools and districts are encouraged to use their own data as well as broader scholarship to inform their work. In this context, a provincial education research strategy was developed, one which involved: (1) contracting universities to write short 'what works' papers for schools; (2) commissioning external evaluations of the strategies adopted; (3) supporting schools and districts in improving their grasp and use of data, so as to guide their own improvement plans, through a specific data-use substrategy. The Student Success Strategy, initiated in 2005, has had a substantial impact on teaching practices and on students' results. Students' test scores have improved markedly and a range of indicators relating to high school improvement also reveal positive read-outs (Levin, 2010).

In Alberta, the value of knowledge for innovation was highly contextual. Here, teachers and school leaders acted as coordinators at different levels, collecting and disseminating research based practices. Ongoing efforts to collaborate with universities and other external partners were revealed as being essential to gathering knowledge about teaching, learning, and instructional improvement. AISI coordinators shared information and planned meetings or workshops for teachers, schools and their partners to build dialogue, share experience and collaborate on future activity (Foster et al., 2008).

Improvement stimulated by outside interventions - for instance, through a specific researchinput or partnership - can have a vital impact on school improvement, but it requires (1) that a range of organisational provisions are made and (2) that forms of social capital - such as collaboration, networking and knowledge sharing - are in place. Finally, the intervention needs to be specifically designed and targeted and those involved, including policy-makers who might be observing the process, need to be aware that any outcomes are always contextual in nature.

\section{Conclusions}

The research evidence on improvement projects presented here clearly demonstrates the links between teacher effectiveness and school improvement and the particular roles played by teacher education and research knowledge. Teachers are the main actors in their classrooms and may promote in complex ways effective learning processes. At the same time, teachers act collaboratively at the school level and have the potential to greatly transform outcomes, by building bridges between classrooms and departments, and by engaging as (and with) leaders and researchers.

Ideally, research infusion from outside or the possession of an inquiry habit of mind in the decision making process (Earl \& Temperley, 2006) may guarantee a horizon of expert knowledge and habits that might lead to school change. However, the relationship between these issues is not 
straightforward or simple. Moreover, teacher policies need to reflect the complexity of teaching, which in turn is influenced by the many elements of teacher quality (King Rice, 2003). The same complexity emerges when the use of research in organisational contexts is analysed. As Levin (2004) notes, "research is embedded in a set of personal and organizational beliefs and practices that are complicated and often deeply entrenched" (p. 5). Having said that, it is however possible to identify some major findings of this article that relate to the opening questions.

First, teacher quality is vital if disadvantaged students are to succeed and disadvantaged schools are to progress and this is intrinsically linked to the quality of initial and continuing teacher education programs (OECD, 2012). Teacher education in all its forms is a major component in the creation of a high-quality teaching force, with relevant research reviews underlining its effects, both on students and on teachers. Teachers' gains are cognitive, attitudinal, self-conceptual and interpersonal in their relationships with their students. Content knowledge and pedagogical preparation needs to be integrated with strong research competencies and focused on preparation for those deemed to be lower achievers in disadvantaged schools.

Second, school improvement depends on having the capacity to improve in place, creating an environment where teacher (and student) morale is high and where there are positive teacher incentives to engage in the change process. School leaders are key actors in all of this. They provide instruction and set out vision, stimulate a positive school culture and act as mediators and stimulators in the process of research production. Low performing and disadvantaged schools improve by getting their staff to improve, training them according to school-specific needs and applying the lessons from school-pertinent research. Schools that emerge positively from such challenges are likely to hold exemplary expertise from which the whole system might benefit.

Third, research, be this delivered or stimulated by external interventions or through on-site collaborative inquiry processes, can make a vital contribution to ensuring effective teaching and learning processes are in place and in building capacity for whole school improvement. The greatest beneficiaries of this kind of 'research-rich' approach are likely to be those who are defined as lower achievers and those in marginalised communities (e.g. Ko \& Sammons, 2012; OECD, 2011, Cordingley \& Mitchell, 2013). Engagement in the research process is indispensable for securing teachers' morale and in building their professionalism. Finally, such research fuels the wider school improvement process, one that is heavily dependent on human and social capital in all its forms.

\section{References}

Alton-Lee, A. (2003). Quality teaching for diverse students in schooling: Best evidence synthesis. Wellington: Ministry of Education

Angrist, J. D., \& Lavy, V. (2001). Does teacher training affect pupil learning? Evidence from matched comparisons in Jerusalem public schools. Journal of Labor Economics, 19(2), 34369.

Boonen, T., Van Damme, J., \& Onghena, P. (2013). Teacher effects on student achievement in first grade: Which aspects matter most? School Effectiveness and School Improvement. Retrieved from http://dx.doi.org/10.1080/09243453.2013.778297

Bryk, A., \& Schneider, B. (2002). Trust in schools. New York: Russell Sage.

Coburn, C. E. (2001). Collective sensemaking about reading: How teachers mediate reading policy in their professional communities. Educational Evaluation and Policy Analysis, 23(2), 145170.

Collins, R., Tagney, N., \& Newham, M. (2012). Self-improving schools. Literature Review. Independent Schools Queensland. 
Colosimo, M. L. S. (1981). The effect of practice or beginning teaching on the self concepts and attitudes of teachers: A quantitative synthesis. Unpublished Ph.D., The University of Chicago, IL.

Cordingley, P., \& Mitchell, R. (2013). Enhancing achievement for vulnerable students: The role of research engagement and knowledge and capacity building in complex systems. Retrieved from http://www.curee.co.uk

Cousins, B., \& Leithwood, K. (1993). Enhancing knowledge utilization as a strategy for school improvement. Knowledge. 14(3), 305-333.

Darling-Hammond, L. (2000). Teacher quality and student achievement. Educational Policy Analysis Archives, 8(1). Retrieved from http://epaa.asu.edu/ojs/article/view/392/515.

Darling-Hammond, L. (2005). Professional development schools. Schools for developing a profession. New York: Teachers College

Darling-Hammond, L., Chung, R., \& Frelow, F. (2002). Variation in teacher preparation: How well do different pathways prepare teachers to teach? Journal of Teacher Education, 53(4), 286315.

Darling-Hammond, L., \& Youngs, P. (2002). Defining "highly qualified teachers": What does "scientifically-based research" actually tell us? Educational Researcher, 31(9), 13-25.

Darling-Hammond, L., Holtzman, D. J., Gatlin, S. J., \& Heilig, J. V. (2005). Does teacher preparation matter? Evidence about teacher certification, Teach for America, and teacher effectiveness. Education Policy Analysis Archives, 13(42). Retrieved from http://epaa.asu.edu/epaa/v13n42/.

Darling-Hammond, L. (2010). Teaching and educational transformation. In A. Hargreaves, A. Lieberman, M. Fullan, D. Hopkins (Eds), Second international handbook of educational change (pp. 505-520). Dordrecht: Springer.

Darling-Hammond, L., Berry, B., \& Thoreson, A. (2001). Does teacher certification matter? Evaluating the evidence. Educational Evaluation and Policy Analysis, 23(1), 57-77.

Dumont, H., Istance, D., \& Benavides, F. (2010). The nature of learning: Using research to inspire practice. Paris: OECD.

Earl, L., \& Katz, S. (2006). How networked communities work. Melbourne: Centre for Strategic Education.

Earl, L. M., \& Timperley, H. (2008). Professional learning conversations: Challenges in using evidence for improvement. Dordrecht: Springer.

Elliott, J. (2009). Research-based teaching. In S. Gewirtz, P. Mahony, I. Hextall \& A. Cribb (Eds), Changing teacher professionalism. International trends, challenges and ways forward (pp. 170-183). New York: Routledge.

Foster, R., Wright, L., \& McRae, P. (2008). Leading and sustaining school improvement initiatives: A review of site-based research from AISI cycles 1, 2, and 3. Edmonton: Alberta Education.

Fullan, M. (2007). The new meaning of educational change. New York: Teachers College.

Fullan, M. (2011). Choosing the wrong drivers for whole system reform. East Melbourne: Centre for Strategic Education.

Furlong, J., Salisbury, J., \& Combes, L. (2003). Best practice research scholarships: An evaluation. Nottingham: DfES.

Furlong, J. (2013). Education - an anatomy of the discipline. Rescuing the university project? London: Routledge.

Greenberg, E., Rhodes, D., Ye, X., \& Stancavage, F. (2004). Prepared to teach: Teacher preparation and student achievement in 8th grade mathematics. Paper presented at the American Educational Research Association Annual Meeting, San Diego.

Greenwald, R., Hedges, L., \& Laine, R. (1996). The effect of school resources on student achievement. Review of Educational Research, 66, 361-396. 
Joslin, P. A. (1980). Inservice teacher education: A meta-analysis of the research. Unpublished Ed.D., University of Minnesota, MN.

Hargreaves, A., Crockere, R., Davis, B., McEwen, L., Sahlberg, P., Shirley, D., \& Sumara, D. (2009). The learning mosaic: A multiple perspective review of the Alberta Initiative for School Improvement (AISI). Retrieved from http://education.alberta.ca/media/1133263/the\%20learning\%20mosaic.pdf

Hargreaves, A., \& Fullan, M. (2012). Professional capital. Transforming teaching in every school. New York: Teachers College.

Harrison, B. (1980). Training English teachers: "The dignity of thinking beings." Use of English, 31(3), 51-61.

Hartman, H. (2001). Metacognition in learning and instruction: Theory, research and practice. Norwell, MA: Kluwer.

Hattie, J. (2009). Visible learning: A synthesis of over 800 meta-analyses relating to achievement. London: Routledge.

Higgins, S., Hall, E., Baumfield, V., \& Moseley, D. (2005). A meta-analysis of the impact of the implementation of thinking skills approaches on pupils. London: Social Science Research Unit, Institute of Education, University of London.

Hopkins, D. (2013). Exploding the myths of school reform. Camberwell: ACER Press.

Ingersoll, R. M. (2007). A comparative study of teacher preparation and qualifications in six nations. Philadelphia, PA: Consortium for Policy Research.

King Rice, J. (2003). Teacher quality: Understanding the effectiveness of teacher attributes. Washington, D.C.: Economic Policy Institute.

Ko, J., \& Sammons, P. (2012). Effective teaching: A review of research. Executive summary report prepared for CfBT. Oxford: University of Oxford, Department of Education.

Levin, B. (2004). Making research matter more. Education Policy Analysis Archives, 12(56). Retrieved from http://epaa.asu.edu/ojs/article/view/211

Levin, B. (2010). How to change 5,000 schools. In A. Hargreaves, A. Lieberman, M. Fullan, M., \& D. Hopkins, D. (Eds), Second international handbook of educational change (pp. 309-322). Dordrecht: Springer.

Levin, B. (2011). Mobilising research knowledge in education. London Review of Education, 9(1), $15-26$

Leithwood, K., Steinbach, R., \& Jantzi, D. (2002). School leadership and teachers' motivation to implement accountability policies. Educational Administration Quarterly, 38(1), 94-119.

Leithwood, K., Seashore Louis, K., Wahlstrom, K., Anderson, S., Mascall, B., \& Gordon, M. (2007). How successful leadership influences student learning: The second instalment of a longer story. In A. Hargreaves, A. Lieberman, M. Fullan, \& D. Hopkins (Eds), Second international handbook of educational change (pp. 661-630). Dordrecht: Springer.

Leithwood, K., Day, C., Sammons, P., Harris, A., \& Hopkins, D. (2006). Seven strong claims about successful school leadership. Nottingham: DfES/NCSL.

Leithwood, K., \& Duke, D. (1999). A century's quest to understand school leadership. In J. Murphy $\&$ K. Seashore Louis (Eds.). Handbook of research on educational administration (pp. 4572). San Francisco, CA: Jossey-Bass.

Marzano, R. (2003). What works in schools: Translating research into action. Alexandria, VA: Association for Supervision and Curriculum Development.

Matanzo, J. B., \& Harris, D. L. (1999). Encouraging metacognitive awareness in preservice literacy courses. In J. R. Dugan (Ed.), Advancing the world of literacy: Moving into the $21^{\text {st }}$ century (pp. 201-225). Carrollton, GA: College Reading Association.

Mayer, R. (2012). Learning with technology. In H. Dumont, D. Istance, \& F. Benavides (Eds.), The nature of learning: Using research to inspire practice. Paris: OECD. 
McCormick, C. B. (2003). Metacognition and learning. In W.M. Reynolds \& G.E. Miller (Eds.), Handbook of psychology: Educational psychology (pp. 79-102). New York: Wiley.

McLaughlin, M., \& Talbert, J. (2006). Building school-based teacher learning communities. New York: Teachers College Pres.

Mourshed, M., Chijioke C., \& Barber, M. (2010). How the world's most improved school systems keep getting better. London: McKinsey \& Company.

Muijs, D., Harris, A., Chapman, C., Stoll, L., \& Russ, J. (2004). Improving schools in socioeconomically disadvantaged areas - A review of research evidence. School Effectiveness and School Improvement, 15(2), 149-175.

Mulford (2010). Recent developments in the field of educational leadership: The challenge of complexity. In A. Hargreaves, A. Lieberman, M. Fullan, M. \& D. Hopkins, D. (Eds). Second international handbook of educational change (pp. 187-208). Dordrecht: Springer.

Musset, P. (2010). Initial teacher education and continuing training policies in a comparative perspective: Current practices in OECD countries and a literature review on potential effects. OECD Education Working Papers, No. 48. OECD: Paris.

Nye, B., Konstantopoulos, S., \& Hedges, L.V. (2004). How large are teacher effects? Educational Evaluation and Policy Analysis, 26(3), 237-257.

OECD (2011). Building a high-quality teaching profession. Lessons from around the world. Paris: Author.

OECD (2012). Equity and quality in education. Supporting disadvantaged students and schools. Paris: Author. Retrieved from http://dx.doi.org/10.1787/9789264130852-en

Palardy, G. J., \& Rumberger, R. W. (2008). Teacher effectiveness in first grade: The importance of background qualifications, attitudes, and instructional practices for student learning. Educational Evaluation and Policy Analysis, 30, 111-140.

Raudenbush, S., Fotiu, R., \& Cheong, Y. (1999). Synthesizing results from the trial state assessment. Journal of Educational and Behavioral Statistics. 24(4), 413-438.

Reynolds, D., Sammons, P., De Fraine, B., Van Damme, J., Townsend, T., Teddlie, C., \& Stringfield, S. (2014) Educational effectiveness research (EER): A state-of-the-art review. School Effectiveness and School Improvement, 25(2), 197-230.

Rowe, K. (2006). Effective teaching practices for students with and without learning difficulties: Constructivism as a legitimate theory of learning AND of teaching? Student Learning Processes. Retrieved from http://research.acer.edu.au/learning_processes/10

Sammons, P. (2007). School effectiveness and equity: Making connections. A review of school effectiveness and improvement research - its implications for practitioners and policy makers. Retrieved from http://www.cfbt.com/en-GB/Research/Research-library/2007/rschooleffectiveness-and-equity-2007.

Seashore Louis, K. (2010). Better schools through better knowledge? New understanding, new uncertainty. In A. Hargreaves, A. Lieberman, M., Fullan, D., Hopkins (Eds). Second international handbook of educational change (pp. 3-27). Dordrecht: Springer.

Seashore Louis, K., Leithwood, K., Wahlstrom, K., \& Anderson, S. (2010). Investigating the links to improved student learning. Final report of research findings. University of Minnesota. Retrieved from http://www.wallacefoundation.org/knowledge-center/schoolleadership/keyresearch/Documents/Investigating-the-Links-to-Improved-Student-

Learning.pdf

Scheerens, J., \& Bosker, R. (1997). The foundations of educational effectiveness. Oxford: Pergamon.

Seidel, T., \& Shavelson, R. (2007). Teaching effectiveness research in the past decade: The role of theory and research design in disentangling meta-analysis results. Review of Educational Research, 77(4), 454-499. 
Stoll, L., Bolam, R., \& Collarbone, P. (2002). Leading for change: Building capacity for learning. In K. Leithwood \& P. Hallinger (Eds). Second international handbook of educational leadership and administration. Dordrecht: Kluwer.

Stoll, L., Bolam, R., McMahon, A., Wallace, M., \& Thomas, S. (2006). Professional learning communities: A review of the literature. Journal of Educational Change, 7, 221-258.

Sumara, D., \& Davies, B. (2009). Using complexity science to study the impact of AISI on cultures of education in Alberta. In A. Hargreaves, R. Crockere, B. Davis, L. McEwen, P. Sahlberg, D. Shirley, \& D. Sumara (Eds). The learning mosaic: A multiple perspective review of the Alberta Initiative for School Improvement (AISI). (pp. 34-50) Retrieved from: http://education.alberta.ca/media/1133263/the\%20learning\%20mosaic.pdf.

Thomson, P. (2010). Whole school change: A literature review. Retrieved from http://www.creativitycultureeducation.org/research-impact/literature-reviews/

Toom, A, Kynäslahti, H., Krokfors, L., Jyrhämä, R., Byman, R., Stenberg, K., Maaranen, K., \& Kansanen, P. (2010). Experiences of a research-based approach to teacher education: Suggestions for future policies. European Journal of Education, 45(2), 331-344.

Thurlings, M., Evers, A.T. \& Vermeulen, M. (2014). Toward a Model of Explaining Teachers' Innovative Behavior: A Literature Review. Review of Educational Research, Published online 12 November 2014 DOI: 10.3102/0034654314557949

Wayne, A. J., \& Youngs, P. (2003). Teacher Characteristics and Student Achievement Gains: A Review. Review of Educational Research, 73(89), 89-122.

Weglinsky, H. (2000). How teachers matter: Bringing the classroom back into discussions of teacher quality. Princeton, NJ: Educational Testing Service.

Whitty, G. (2006). Teacher professionalism in a new era. Paper presented at the First Teaching Council for Northern Ireland Annual Lecture, Belfast.

Wiliam, D. (2013). The importance of teaching. In J. Clifton (Ed). Excellence and equity. Tackling educational disadvantage in England's secondary schools. London: Institute for Public Policy Research.

Zohar, A. (1999). Teachers' metacognitive knowledge and the instruction of higher order thinking. Teaching and Teacher Education, 15, 413-42 